University of Wollongong

Research Online

Faculty of Law, Humanities and the Arts Papers (Archive)

Faculty of Arts, Social Sciences \& Humanities

$1-1-2014$

Tone it down a bit!: euphemism as a colonial device in Australian Indigenous studies

Colleen McGloin

University of Wollongong, cmcgloin@uow.edu.au

Follow this and additional works at: https://ro.uow.edu.au/lhapapers

Part of the Arts and Humanities Commons, and the Law Commons

Research Online is the open access institutional repository for the University of Wollongong. For further information contact the UOW Library: research-pubs@uow.edu.au 


\title{
Tone it down a bit!: euphemism as a colonial device in Australian Indigenous studies
}

\begin{abstract}
In a previous article discussing the politics of language in Australian Indigenous Studies teaching and learning contexts, my colleague and I stated our objective in writing that article was to "instill" a sense of the importance of the political nature of language to our student body (McGloin and Carlson 2013). We wanted to engage students in the idea that language, as a conduit for describing the world, is not a neutral channel for its portrayal or depiction; rather, that it is a political device that is often a contributing force to racism and the perpetuation of colonial violence. While reviews of the article were favorable to, and enthusiastic about its aims and content, and some suggestions for refinement helpful, one of the reviewer's comments presented a quandary: we were advised to replace the word instill (as in the above context) with develop, a term considered "less invasive." In stating that our aim was to develop a sense of the importance of language, we were advised, our article would better "recognise the varying trajectories of student learning." After much consideration, we declined this suggestion contending that the word instill fit the aims of the article in that were introducing a practice that would inculcate the importance of language in Indigenous contexts.
\end{abstract}

\section{Keywords}

studies, bit, euphemism, indigenous, australian, device, colonial, tone, down

\section{Disciplines}

Arts and Humanities | Law

\section{Publication Details}

McGloin, C. (2014). Tone it down a bit!: euphemism as a colonial device in Australian Indigenous studies. Review of Education, Pedagogy, and Cultural Studies, 36 (2), 156-167. 
Tone it Down a Bit! : Euphemism as a colonial device in Australian Indigenous Studies

Dr Colleen McGloin

Senior Lecturer, Indigenous Studies Unit

Faculty of Arts

University of Wollongong

Telephone: +61242214894

Email: $\underline{\text { cmcgloin@uow.edu.au }}$

Colleen McGloin is a senior lecturer in Indigenous Studies at the University of Wollongong, NSW, Australia. Her background is in cultural studies and her current research focuses on pedagogy, policy, and praxis in higher education.

Shortened Title: Tone it Down a Bit

This paper has not been published elsewhere and has not been submitted simultaneously for publication elsewhere. 
Tone it Down a Bit! : Euphemism as a colonial device in Australian Indigenous Studies Colleen McGloin

Historical learning ... is not about constructing a linear narrative but about blasting history open, rupturing its silences, highlighting its detours, acknowledging the events of its transmission, and organizing its limits within an open and honest concern with human suffering, values, and the legacy of the often unrepresentable or misrepresented.

-- Henry A. Giroux “Cultural Studies, Public Pedagogy, and the Responsibility of Intellectuals"

Problem-posing education ...enables teachers and students to become Subjects of the educational process ... [T] he world - no longer something to be described with deceptive words - becomes the object of that transforming action by men and women which results in their humanization.

-- Paulo Freire Pedagogy of the Oppressed

\section{INTRODUCTION}

In a previous paper discussing the politics of language in Australian Indigenous Studies teaching and learning contexts, my colleague and I stated our objective in writing that paper was to 'instil' a sense of the importance of the political nature of language to our student body (McGloin \& Carlson). We wanted to engage students in the idea that language, as a conduit for describing the world, is not a neutral channel for its portrayal or depiction; rather, that it is a political device that is often a contributing force to racism and the perpetuation of colonial violence. While reviews of the paper were favourable to, and enthusiastic about its 
aims and content, and some suggestions for refinement helpful, one of the reviewer's comments presented a quandary: we were advised to replace the word "instil" (as in the above context) with "develop," a term considered "less invasive." In stating that our aim was to "develop" a sense of the importance of language, we were advised, our paper would better "recognise the varying trajectories of student learning." After much consideration, we declined this suggestion contending that the word 'instil' fit the aims of the paper in that were introducing a practice that would inculcate the importance of language in Indigenous contexts. Our thoughts were that such a practice went beyond a gradual developmental process. Indeed, instilling the importance of language by using concrete examples of its application, and its effects, in our view, should be the starting point of a critical pedagogical practice in anti-colonial studies. The term "develop" suggested less immediacy than we wanted to convey about what we thought a serious issue for our students, our discipline, and those interested in work that examines language use for the purpose of disclosing its significatory potential and its capacity for mis-representation. So while grateful for suggestions for improvement, the irony of substituting a "less invasive" term was not lost on us and has inspired this writer to return to the terrain with the aim of further understanding the capacity of language to seamlessly naturalise, and to level and conflate difference as much as to mark otherness. I invoke the anecdote of the review process not in arrogance or disrespect but to illustrate the way in which language is often euphemised for the purpose of palatability or social convention. In this paper, I want to emphasise the importance of language, in all its contexts, following Bakhtin (1992), to tease out those "varying degrees of otherness or varying degrees of "our own-ness" in what is spoken and what is heard, what is understood and misunderstood (89).

This semantic wrangling might appear trivial to some in the continually revived climate of $p c$ sensibilities in Australia, but it cuts to the crux of this writer's concerns about 
how language operates politically to control, silence, marginalise, mis-represent, and how we, as educators are constantly censored and moderated in our use of language. As Fanon (1967) showed, the effects of language are deeply political. Language is a channel for the construction of racialised, and often racist significations which, he argued, are internalized psychically through the language and culture of the colonising forces. In teaching and learning contexts, resistance to Fanon's ideas about language is commonplace. I can cite numerous instances where the political differences implicit in the terms "settlement" and "invasion" in reference to colonisation have generated heated debate and where usually, the term "settlement" is preferred by many who find invasion - simply too invasive. In reference to "invasion" and "settlement" as terms that describe the specific historical event that occurred in Australia in 1788 when colonising forces dispossessed Indigenous people of their land, it is not really the point to argue emphatically that one term is right, and the other wrong; indeed there are a range of standpoints on this from a range of scholars engaged in anti-colonial studies. What is more beneficial is a conversation about language use per se, a dialogue where we can flesh out how and why terms signify in particular ways and what power relations discursively shape that usage. The intention of foregrounding language use is to try to "instil" a consciousness about how we speak through unpacking the politics implicit in all forms of representation. A rigorous approach to how language shapes meaning in pedagogical contexts also reveals whose interests are being served through particular referents and modes of expression, and importantly, whose interests are not served.

This paper is underscored by these propositions with a particular view to the use of euphemism in pedagogical contexts where content is political and can often be sensitive and confronting. I ask how euphemism functions linguistically as a narrative filter, specifically in relation to the teaching of Indigenous Studies where anti-colonial politics are central to the discipline's objectives both in research and pedagogical praxis. ${ }^{1}$ The ideas expressed here 
might also be useful in all teaching and learning situations where notions of difference are central, and where language and representation reflect perceptions of difference as these are constructed discursively across a range of institutional sites and contexts. This paper will build on previous work by further complicating the politics of language in contexts of sociocultural difference in order to draw attention to its usage and to make visible that which is hidden, unspeakable, offensive, or deemed unpalatable, by examining closely the use of euphemism as it shapes public pedagogy and cultural politics in broader discursive terrains. Euphemism shapes all institutional speech codes. It is a social phenomenon that functions as an invaluable linguistic device for the forces of neoliberalism as they both reflect and shape public pedagogy, and in turn, public opinion regarding issues of cultural difference. In relation to how this affects practitioners in the field of higher education, the paper considers also, following Giroux, 'that our responsibility as public intellectuals cannot be separated from the consequences of the knowledge we produce, the social relations we legitimate, and the ideologies and identities we offer up to students (2004a, 500).

The aim of the paper is not to encourage a wholesale censoring of language or to incite dysphemism for the sake of a perceived "truth." Nor am I interested in curbing the linguistic creativity of metaphoric speech. What I want to disclose is the way that we use metaphor, in this instance euphemism, and to make sense of how it functions discursively to buffer certain perceptions about "otherness" by obfuscating realities, histories and lived experiences. I'm interested in what cannot be said, what is left out of the telling of violent histories and how this affects both the subjects under erasure and those doing the erasing. Why do we "tone down" events, histories, and practices that are too difficult, too political, or too emotionally loaded to be uttered? And how does the sanitising of historical events affect those doing the narrating as well as those who are subjects of narrative? For, it is in part this process of obfuscation through language use, I would argue, that leaves in situ dominant 
colonial relations of power. Finally, I offer some insight into the reason for students' use of euphemism in Indigenous Studies and argue for a praxis whereby effective strategies for addressing euphemism might be developed through sustained dialogue about the politics of language.

\section{Euphemism: Origins and discursivities}

The term euphemism derives from the Greek eupheme: eu/good, pheme/speaking. Eupheme was the name of the woman who was nurse to the Muses of ancient Greece. The term refers to the use of "fair words" or "words of good omen" (Keyes 2010, 7). It is perhaps no accident that the "taming" of language is accorded a gendered source. Euphemism is a linguistic trope that stands in, often, for what cannot be uttered due either to deference to discourses of propriety, or in cases where a literal term is deemed unspeakable. Euphemisms are part of the ebb and flow of communication, metaphors that make life bearable by obscuring what is considered in this discourse to be unthinkable or unsayable. Euphemisms are what might be called a "conversational lubricant" (Borowitz 2008, 1), a slang term or "stand in" that ameliorates, is less invasive or harsh than what it replaces. LaPointe (2011) suggests euphemisms "dampen our deepest fears" (vii). Aronson (2007) points out that they can act as a "congenial synonym," a more palatable way of saying the same thing (71). Euphemisms abound in all cultures as perhaps the most common application of metaphor, a disguise that takes advantage of the flexibility of language (Miller 1986, 129, 130). Gerry Abbott (2010) claims, "the more delicate the social situation and the more unpleasant the subject matter we refer to, the more careful we must be in selecting a euphemism for the purpose" (51). For example, being in poverty is often scripted as "disadvantage," the sacking of an employee described as "letting them go." As linguistic referents, euphemisms have the power to dilute lived experiences, to soften or make bearable utterances that might shock or horrify an audience, or otherwise transgress social niceties by shutting down "polite 
conversation." In the context of teaching anti-colonialism, however, euphemisms are not merely placatory manoeuvres for sidestepping the lived realities of Indigenous people; they are linguistic devices capable of depoliticising and as such, are powerful colonial tools that require close scrutiny. Euphemisms can be harmful, offensive, insulting in their capacity to remove subjects from their histories thereby destabilising any sense of self that equates with personal experience, as Butler (1997) notes, "[T]o be injured by speech is to suffer a loss of context, that is, to not know where you are" (4).

Euphemisms are an effect of the ideals of decorum that inform dominant discourses of propriety. These discourses dictate not only that some terms exceed the limits of social politeness, but also, that their usage can incur negative penalties for exceeding the bounds of discourse. Repercussions for transgressing discourse can include ridicule, mockery, expressions of disapproval, and marginalisation. Student anecdotes tell us that Indigenous Studies and the politics of anti-colonialism is not very popular with many of their contemporaries. Students often express the challenges this presents them as learners in this field. Indigenous Studies, students tell us, is not considered by some peers and family members as a valid area of study for a range of reasons accorded to many humanities disciplines that aren't "training” students for particular employment prospects. Others, we are told, see the content as "too political," or "too radical", a threat to official national narratives. As stated the majority of our cohort are non-Indigenous students, many of whom come from families who still uphold stereotypical and racist views about Indigenous people. The impetus to tone down discussion with euphemistic language is part of a pervasive discourse, therefore, that positions students in the discipline as possible transgressors, not only of deference to $p c$ discourses but of concerns about nation-building. Perhaps in some cases also, euphemism is a mark of resistance driven by the proposition that mindfulness about language demands a more strident engagement with Indigenous politics. As I've noted, if language has been 
depoliticised, then critical engagement becomes difficult, if not impossible. (As I write, it is reported that a young woman in Sydney has been 'sexually assaulted' by five men [ABC online]. A brief investigation of this story from various sources discloses the use of euphemism to publish what is in fact a brutal gang rape, but such language exceeds the limits of discourse, unless perpetrators are racialised as "Other").

On one level it is no surprise that many of our students resort to tempered descriptions of colonial tragedy; in addition to familial and peer pressures, most of our current students were raised in the years of conservatism that heralded what was referred to as the "history wars" in this country, a time when the then Prime Minister, John Howard railed against revisionist historians and any suggestion that Australia had a past that was shameful. Howard was outspoken in his attack on revisionism during his reign and he continues to expound on what he sees as revisionist history's attempts to provide a more inclusive account of Australia's colonial history in Australia's school syllabus:

The curriculum does not properly reflect the undoubted fact that Australia is part of Western civilisation; in the process it further marginalises the historical influence of the Judeo-Christian ethic in shaping Australian society and virtually purges British history from any meaningful role. (Howard cited in Shanahan)

On another level, though, I suspect there is more to be said about the reasons for euphemistic usage in Indigenous Studies classrooms and I will come to this. First, I want to consider euphemism as a useful device for promoting particular accounts of nation-building.

\section{Euphemism and Nation-Building}

Students come to University well-versed in the dominant narratives of colonialism: they are all familiar with Captain Cook, they usually endorse Australia Day and other national celebrations and symbols. They often express national pride invoking a range of familiar 
national myths and narratives and are conversant with the myth of 'peaceful settlement' articulated widely in various media. Students' sense of civic identity has been produced through public sites such as education and various forms of media as well as being validated by familial institutions, religious and legal organisations. It is hardly surprising that when they enrol in Indigenous Studies, students have acquired a considerable repertoire of knowledge about dominant discourses of nation and the affirmation of nationalism through certain rituals and traditions. Introducing Indigenous accounts of history and contemporary struggles can come as quite a shock then; students are often in disbelief at the extent of suffering, the ongoing struggles, health statistics, early mortality rates, parliamentary inquiries, and colonial legislation that continues to regulate Indigenous people in this country. They are also often surprised to discover that Indigenous people have a different knowledge system based on thousands of years of knowledge and survival as well as a burgeoning oeuvre of contemporary critical work that challenges perceived "truths" about the world. As Giroux (2004a) notes, the organising force of neoliberal ideology “operates within a variety of social institutions and formats" (498) producing a strong sense of nation and in many cases, national pride that has as its locus the myth of "peaceful settlement." The myth of "peaceful settlement" underscores a more urgent preoccupation in neoliberal ideology: the promotion of a unified nation-state. Indigeneity disrupts the nation-state, and Indigenous Studies as a set of pedagogical practices, destabilises the broader discourse of neoliberalism that informs the University where, despite contestation, it is now widely taught in many institutions, following a long continuing struggle for recognition where "the content, processes, methods, and forms of education are also a contested matter, caught up as they are in the colonial and decolonial impulses" (Nakata et al 2012, 123).

The manifold sites of public pedagogy students are exposed to function to produce and support knowledge that is depoliticised for the purpose of creating and maintaining a 
compliant and complicit body politic whose unswerving loyalty to nation is deeply and uncritically ingrained into all public areas of knowledge production. One of the exceptions may be higher education where knowledge and ideals offer a promise for social justice (Giroux 2004a, 498), and in some institutions, where Indigenous knowledge is validated within the disciplinary arena of humanities studies. This is not always a straightforward proposition, however, as suggested, both Indigenous and non-Indigenous students taking Indigenous Studies courses are differentially positioned by a range of vested interests when they arrive(Nakata et al 2012, 123). It is often the case therefore, that educators in the field must work hard to find effective ways of 'undoing' the systematic and uncritical indoctrination of national affiliation inscribed in neoliberal ideology before attempting to introduce ideas that subscribe to completely different notions of connection to, or love of country.

\section{'Free' speech}

Much poststructuralist work in the area of language points us to the instability of language, its potential for meanings, its multifarious and polyvocal dimensions. Nietzsche (1979) asserted "we possess nothing but metaphors for things - metaphors which in no way correspond to the original entities"(81-82), and Derrida (1990) referred to the constant "play of signs," arguing that "the presence of an element is always a signifying and substitutive reference inscribed in a system of differences and the movement of a chain" (294). Confirming the link between ideology and language, Bakhtin (1984) claimed "there can be no such thing as an absolutely neutral utterance" (6). Struggles over language are also central to much feminist research (Mills and Mullany 2011, 144) where activism regarding language use has had a direct impact over the decades on much workplace policy where terms deemed offensive, gender blind, or simply out of date are now replaced by terms decreed more appropriate. Theories of language have formed a basis for studies in representation, film, literature, and television 
studies. Most students in the humanities learn that social relations are mediated through language, and that language has the capacity to construct - and deconstruct - subjectivities.

In Indigenous Studies, a focus on language and representation is crucial in disclosing colonial relations of power and their effects, and in considering how we might re-present Indigenous histories and worldviews, and indeed, how Indigenous people might choose to self-represent. But as I have indicated, resistance towards so-called $p c$ sensibilities often reveals an ideological position that demonstrates commitment to the dominant discourse of so called "free" speech, itself a mantra of neoliberal constructions of democracy. According to this discourse, the fantasy of unregulated speech codes is extoled in the public domain as a hallmark of democracy. This is despite what are often obvious constraints of social propriety that regulate what can and can't be said in some contexts but not in others. For example, when "free speech" becomes a potential force of dissent to the forces that attempt to fix meaning in the public domain according to concerns about nation, official regulation replaces the fantasy of "free" speech: in Australia's current election campaign the incumbent Labor Prime Minister, Kevin Rudd has told the Australian public, "Ours is a truly great country; nobody should ever talk this country down" (Rudd, 2013). This sentiment has been echoed repeatedly by politicians from both parties and its force does not go unrecognised by many of our students who struggle with the prospect of critiquing nation and national sentiment, and especially so when exposed to the content in Indigenous Studies which teaches them that ideas of nation(s) and country(s) are enshrined in very different epistemes in Indigenous contexts in Australia (see McGloin 2006, 176) In discursive terms, there is no difference between what Howard and Rudd have to say about the nation; both are keen to denounce any detractors as wrong-doers. This form of utopian social engineering affects students' ability to critically engage with ideas about knowledge, power, or the production of "truth," and 
especially in Indigenous contexts where oppositional modes of knowledge are central to the discipline and to the politics of Indigenous struggles.

Although this prescribed positivism presents a problem for educators in the field, it is not insurmountable; as well as being discursively imbued with neoliberal ideology, it is also the case that young students are creative and often interested in critical thought in order to better understand the world they occupy. That they arrive ill equipped is not solely their problem: on the contrary, it is our responsibility to find effective ways of countering the effects of dominant discourses. It is a challenge though. Public pedagogy in this country reflects neoliberal thinking where democracy is reduced to notions of individual choice and freedom: we are "lucky" to be "free," to have "choices," "rights," and so on. Moreover, students echo the familiar prescription that if we don't like the government, we can vote them out. Democracy in this schema is a simple set of practices and ideologies that uncompromisingly endorse nationalist sentiment. Artfully removed from any capacity for broader signification, democracy becomes a mark of Australian-ness, neatly located "outside" of the socio-political spheres of knowledge and power. The power to "tone down" the language can be understood in this context where myths of the "lucky country" are implicit to any articulation of national identity.

\section{Toning Down the History}

The following represents a small sample of words and phrases used in essays, on line assessments and class presentations from students in their first year of Indigenous Studies. I hasten to add that the italicised usage is commonplace and not particular to any group but are used by all students, bearing in mind that a majority of our students are female and nonInidgenous.

- In 1788 Aboriginal people were dispossessed of their land

- In 1788 Australia was settled by white colonisers. 
- Evidence suggests that in many areas, Aboriginal people were badly treated by European settlers.

- Many Aboriginal people lost their families because of colonial policies.

- Following colonisation, Indigenous Australians have experienced cycles of poverty

- While some colonisers made an attempt to learn Aboriginal languages, many weren't very understanding about Aboriginal culture.

- There is some evidence that Aboriginal women were mistreated by white men.

- On the south coast of New South Wales, colonisers acquired large landholdings.

- There is a gap between the health outcomes for Indigenous and non-Indigenous Australians

The above examples are not unusual. Nor are they particularly incorrect. They are rather, inaccurate and euphemistically encoded palliatives to the violent physical, psychical, and psychological effects of colonialism. Often in passive voice and past tense, they signal a desire to tone down or obscure what Halmari (2011) refers to as "life's harsh realities" (828). As "stand in" phrases and terms, the above descriptions do what they are designed to do: they conceal, modulate, and make palatable, but at the level of signification, they stop short of uttering anything meaningful about the lived experiences of Indigenous people. Alternative and more accurate expressions such as, say, "forced to relocate," "invaded," "state sanctioned murder," "forcible abduction by State authorities," "rape," "inhumane cruelty" are beyond the range of linguistic expression, to be fair, not as a result of ignorance, but from a deep desire to find in euphemism a language that can be lived with, that does not induce guilt. According to Kany's work on euphemism, "a speaker resorts to euphemism in order to disguise an unpleasant truth, veil and offense, or palliate indecency" (italics my emphasis) (Kany in Gómez 2009, 727). 
The notion of indecency is relevant in this context; this is precisely what students wish to avoid. Looking closely at the socio-political effects of some of the above pacifications, the use of past tense functions not only to relocate colonial violence to a bygone era, it also deftly removes responsibility for these actions from the perpetrators and transfers it to the violated: if you are dispossessed, your land settled by white colonisers, you've "lost" your family, or were "mistreated," the implication is passivity in these acts: they simply happened to you. Questions of agency are neatly disarticulated as are notions of intent. The how or why of colonial brutality is carefully concealed beneath metaphorical expressions of passivity that bolster stereotypical notions of the "passive" or "peaceful" native central to colonial discourse. What is palpable having read many similar comments from students are the efforts made here to avoid indecency, "life's harsh realities," or any expression that transgresses social propriety or that would allow for any meaningful understanding of the effects of colonisation on Indigenous subjects. These are not random selections of phrases; indeed, I would suggest they are quite carefully considered and selected. So the question for me is not how this occurs. As I've stated, the discourses that regulate linguistic speech codes according to a prescribed $p c$ mantra are powerful. The more pressing inquiry is why students find certain truths about colonialism so un-utterable, so indecent in pedagogical contexts where they are taught about the politics of language.

In part this can be attributed to the gendered nature of language and the multitudinous ways female subjects are acculturated by discourses of propriety. As Sara Ahmed (2010) attests, "[F]eminist consciousness can be thought of as a consciousness of the violence and power that are concealed under the languages of civility" (86). Ahmed is interested in the way in which happiness, its pursuit and expression, has become discursified across many cultural contexts and how the history of happiness is encoded in the colonial project. She notes that “[E]mpire' becomes a moral and pedagogic project of improving manners, a 
project of cultivation" (127) and that "colonialism is justified as necessary not only to increase human happiness but to teach the natives how to be happy" (128). This in part helps to explain the gendering of speech codes that refuse to allow for disquiet, dissonance or critique. As Ahmed (2010) argues, happiness is central to imperialism and citizenship, and to nation-building $(130,133)$. In thinking about euphemistic usage as a pedagogical device for toning down colonialism, however, there is something else to consider, and that is the ways in which colonial histories produce in students feelings of guilt and shame.

\section{Placating Guilt and Shame}

Historian Henry Reynolds (2000) explains that those asking why they were never told the events of Australia's colonial history from the perspective of Indigenous people "felt that they should have known ...[T] hey believed their education should have provided the knowledge, the information, and hadn't done so. They felt let down, cheated, sold short" (2). Often accompanying the knowledge that so much information was deliberately omitted from school curricula is a level of anxiety in students that leads to a feeling of guilt not only about colonial violence but also about its enduringness and their own potential complicity in this. That students feel guilty is not a response to pedagogical method: it is a consequence of learning at University what in most cases was not taught at school. Colonial histories, their attendant theories and analyses are new to most students at University and the sudden realisation, to use Reynolds words, that they were "cheated" can be jolting. It is the case that for the majority of our students who are female and non-Indigenous, an overwhelming sense of guilt accompanies the shock of learning, at times immobilising their efforts to intellectually and truthfully engage with the complexity of thinking required to understand colonial violence. Euphemism in these instances offers distance, from violence, from the "self" as a potential accomplice, and from the guilt associated with discovering the extent and enduringness of colonial tragedy. 
Palliatives act as retreats into linguistic safety. They need little thought and can avert the omnipresent spectre of guilt that offers no pedagogical value to students and is often unproductive in any meaningful sense as it can immobilise students into a subjectivity that denies hope, any potential for transformation, or the prospect of improvement in the political struggles of Indigenous people. Guilt and shame ${ }^{2}$ often work therefore in unproductive ways to simply reinforce themselves. More worryingly, feelings of guilt and shame about the enduringness of colonialism can function to produce resistance to colonial critique. For some, it's much easier to digest palatable pioneering versions of history that serve well in the workplace and make for tranquil familial and social relations. For others, the prospect of questioning their entire education prior to University is daunting; if so much has been omitted, how reliable is other knowledge acquired? What else has been left out? Are there other important silences that need to be uncovered? How are we to understand the relationship between pedagogy, power, and the broader field of education where curriculum is developed according to validating some forms of knowledge and completely erasing others? These questions arise often in Indigenous Studies and I'm reminded of Marcherey's (1990) consideration that textual silences are "not a lack to be remedied, an inadequacy to be made up for" (215), but a necessity we must try to distinguish.

\section{Tempering Euphemism}

Martin Nakata (2012) expresses concern about how non-Indigenous students might "come to understand the depth and complexity of the challenges Indigenous people confront in trying to pursue their goals" (126). If understanding these challenges is continually thwarted by language codes that refuse to acknowledge their complexity, then it is crucial for students to be cognizant of the many public sites where language codes are produced, taught, and reinforced. Embedding knowledge about how language works into course modules and class discussions is essential in teaching anti-colonialism and anti-racism. As a core practice in 
anti-colonial studies, knowledge about language extends to an understanding of its sources, origins and intentions, its discursive, cultural and pedagogical functions, and most importantly, its effects. Such knowledge is crucial for students if we are to engage them in critiques of colonialism. This is a daunting task, made worse by a marriage between neoliberalism and higher education which continues to produce both teachers and learners according to the hallmarks of a corporate culture that validates some forms of knowledge at the expense of others (Giroux and Searls-Giroux 2004, 225). But it also presents a challenge for transformative practice where possibility and hope can create sites of resistance. In this space of transformation, students can begin to see themselves as critical agents who have understood the power relations that play such a powerful role in producing their acquiescence to nationalist sentiment. Coming to terms with language use and understanding its powerful role in the maintenance of Indigenous subjectivities will also provide a clearer, more rigorous basis for contestation. And addressing the "toning down" of language as a broader set of discursive and pedagogical practices will uncover some of the silences, erasures, and omissions that render non-Indigenous students as critical allies ${ }^{3}$ and social justice activists.

\section{Conclusion}

The use of euphemism in anti-colonial praxis is not particularly new or innovative. It is part of a broader network of discourses that inform public pedagogy and the "taming" of modes of expression that unsettle dominant discourses of nation, propriety, gender construction, and intellectual rigour. Euphemism is an assault on Indigenous struggles; it is a powerful colonial device that tempers violence and repudiates colonial atrocities by encoding them in a language of safety. Colonial power relations remain secure through euphemistic usage because euphemism functions to deny a past that conflicts with dominant nationalist sentiments while simultaneously refuting a present whose legacy is a direct consequence of colonial invasion. A pedagogical praxis that validates other knowledge systems, that 
interrogates language use and origins, and that teaches an ethical approach to Indigenous Studies can be located in aspirations of transformation and hope. Firstly, though, it must unsettle the known and the unknown: what has been given as fact, and what has been omitted or invalidated. Transformative practice in teaching anti-colonialism must interrogate language by asking why its conventions are discursively produced according to truths that might threaten, disrupt, or destabilise colonial power relations.

References

ABC news 4 March (2013). Retrieved from, http://www.abc.net.au/news/2013-03-03/groupallegedly-sexually-assault-sydney-woman/4550604

Abbott, G. (2010). 'Dying and Killing: euphemisms in Current English,' English Today, 104, 26: 4 pp. $51-52$.

Ahmed, S. (2010). The Promise of Happiness, Durham \& London: Duke University Press. Aronson, S. M. (2007). 'Euphemisms, Dysphemisms and Blasphemy', Medicine and Health Rhode Island, 90:3.

Bakhtin, M. (1984). Problems of Dostoyevsky's Poetics, edited and translated by Caryl Emerson, Minneapolis: University of Michigan Press. 
(1992). The Dialogic Imagination: Four Essays. Austin: University of Texas

Press.

Borowitz, A. (2008). 'Couching the Truth' Town and Country, NY: Hearst Magazines.

Butler, J. (1997). Excitable Speech, London \& NY: Routledge.

Derrida, J. (1990). ‘Structure, Sign and Play’ in Writing and Difference, Alan Bass (Trans.), London: Routledge.

Fanon, F. (1967). Black Skin, White Masks, C Markmann, (Trans.), NY: Grove Press.

Freire, P. (1996). Pedagogy of the Oppressed, London \& NY: Penguin.

(1998). Pedagogy of Freedom, P. Clarke (Trans.), Lanhan, MD: Rowman \&

Littlefield.

(2005). Teachers as Cultural Workers, Colorado: Westview Press.

Geetha, V. (2011). 'Taboo and Euphemism in Tamil, Language in India, 11:12,pp 231-236.

Giroux, Henry A. (2004a). 'Public Pedagogy and the Politics of Neo-liberalism: making the political more pedagogical, Policy Futures in Education, V.2 Numbers 3 \& 4, pp. 494-502. (2004b). 'Cultural Studies, Public Pedagogy, and the Responsibility of Intellectuals',

Communication and Critical/Cultural Studies, Vol.1. No. 1. March, 2004, pp. 59-79.

Giroux, H A, Searls Giroux, S, (2004).Take Back Higher Education, Hampshire; Palgrave Macmillan.

Gómez, Miguel Casas, (2009). 'Towards a New Approach to the Linguistic Definition of Euphemism’ Language Sciences, 31, pp725-739.

Halmari Helena, (2011). 'Political correctness, euphemism, and language change: The case of 'people first', Journal of Pragmatics, 43. Pp. 828-840.

Rudd, K. (2013), in Henderson, G. The Sydney Morning Herald, available at http://www.smh.com.au/comment/rudd-has-taken-a-leaf-out-of-the-negativity-book20130805-2ra2m.html 
Lorde, A. (1984). Sister outsider: Essays and speeches. NY: Crossing Press.

McGloin, C, Carlson, B. (2013). 'Indigenous Studies and the Politics of Language,' JUTLP, Vol.10, Issue 1.

Macherey, P. (1990). 'The Text Says What it Does Not Say', Literature in the Modern World: Critical Essays and Documents, in Dennis Walter (Ed.), Oxford: Oxford UP., 215222.

Nakata, M, Nakata, V, Keech, S Bolt, R. (2012). 'Decolonial goals and pedagogies for Indigenous Studies, Decolonisation: Indigeneity, Education and Society, Vol.1 No.1. pp. 120-140.

Keyes, Ralph, (2010). Euphemania, NY: Little, Brown and Company, 2010.

LaPointe, L. (2011). 'Euphemisms', Editorial, Journal of Medical Speech Language Pathology, 19:2, p. vii-viii.

McGloin, C. (2008). Surfing Nation(s), Surfing Country(s), Saarbruken, VDM Verlag. Mills, S. Mullany, L.(2011). Language, Gender and Feminism, NY: Routledge.

Miller, Donald, F. (1986). 'The Necessity of Euphemism', Diogenes, 34:129, pp. 129-135. Nakata, M. Nakata, V. Keech, S. \& Bolt, R. (2012). 'Decolonial Goals and pedagogies for Indigenous Studies', Decolonzation: Indigeneity, Education and Society, Vol.1 No.1, pp. 120-140.

Nietzsche, F. (1979). 'On Truth and Lies in a Nonmoral Sense', in: Philosophy and Truth. Selections from Nietzsche's Notebooks of the early 1870's, Daniel Breazeale, (Trans \&Ed.), New Jersey: Humanities Press. pp. 79-91.

Orwell, G, (1946). 'Politics and the English Language', Retrieved from www.mytholyoke.edu/acad/intrel/orwell46htm 1946. 
Shannahan, D. (2012). 'Howard revives history wars in attack on Labor curriculum' The

Australian, Retrieved from http://www.theaustralian.com.au/national-affairs/education/john-

howard-revives-history-wars-in-attack-on-labor-curriculum/story-fn59nlz9-1226482959782.

Reynolds, H. (2000) Why Weren't We Told, Victoria, Penguin.

Xiaonan. Z, Dong, J.(2010). 'Study on the Features of English Political Euphemism and its

Social Functions,' English Language Teaching, 3:1, pp. 118-121.

\footnotetext{
${ }^{1}$ Indigenous Studies at the University of Wollongong gives emphases to both Aboriginal and Torres Strait Islander peoples and histories. Our student cohort in Indigenous Studies at first year level consists of approximately five percent of Indigenous students although this number is growing. The remainder are nonIndigenous students from the locale, from a range of ethic and cultural backgrounds, ages and class backgrounds. We are also hosts to sessional cohorts of international students primarily from the United States. In most of our classes the balance of female to male students would be in the ratio of 10:4.

${ }^{2}$ I am aware I am conflating notions of guilt and shame and that these have particular disciplinary connotations in psychology. It is my observation that what manifests as guilt or shame in students in Indigenous Studies are an effect of neoliberal discourses that construct the nation state according to particular discourses of nationalist sentiment that don't allow for critique. I note also that guilt and shame cross over to varying degrees and can be understood in collective contexts, (e.g. where collective shame is warranted and can in some instances have a productive pedagogical function) or experienced as individual responses that can be immobilising and counterproductive to critical engagement.

${ }^{3}$ The concept of "critical allies" is used to refer to non-Indigenous people engaging with Indigenous people and struggles from a standpoint of alliance that both recognises, and seeks to disrupt, colonial power relations. Questions regarding what it means to be a critical ally are central to my current research.
} 